\title{
Effect of Health Education Program on Knowledge and Attitude of Mothers of a Febrile Convulsive Child
}

\section{Hanaa S. Said ${ }^{1^{*}}$, Hala A. El-Maghawry ${ }^{2}$}

${ }^{1}$ Department of Family Medicine, Faculty of Medicine, Zagazig University, Egypt.

${ }^{2}$ Community, Environmental and Occupational Medicine Department, Faculty of Medicine, Zagazig

University, Egypt

\section{Abstract:}

Background: febrile convulsion (FC) in children is a common presentation in family medicine and pediatric clinics. Parental anxiety and fear of fever are often related to inadequate knowledge.

Objective: to assess the effect of health education program on knowledge and attitude of mothers regarding febrile convulsion.

Methods: an intervention study was conducted on 32 children. The study was implemented in Zagazig health district which is the capital of Sharkia governorate. Two family health centers were selected randomly to represent the district. Participants' information regarding FC was collected via the KACP questionnaire.

Results: The study revealed that only $18.8 \%$ of the studied sample had an adequate total knowledge regarding FC, $87.5 \%$ total positive attitude and about one third of the studied mothers had an appropriate knowledge regarding first aid and home management during the FC attack (preprogram), which greatly improved with high statistically significant difference after implementing the health education program.

Conclusion: Parental fear of fever and febrile convulsion could be declined through appropriate health education sessions discussing all aspects of the disease and possible complications and how to prevent it.

Keywords: Children, fever, first aid, Sharkia, management.

\section{Introduction:}

Febrile convulsion (FC) is the commonest neurological presentation in childhood, as it generally defined as attacks of seizures occurring in children typically aged from 6 months to 60 months concomitant with fever over $38{ }^{\circ} \mathrm{C}$ in absence of other causes of seizures like (intracranial causes, electrolyte imbalance, hypoglycemia, drug use or drug withdrawal, or a history of an afebrile seizure). ${ }^{(1)}$

The peak incidence of febrile convulsions is at 18 months. About 6-15\% of febrile convulsion attacks occur after the age of 4 years and onset after 6 years is very unusual. (2)

Febrile convulsion affects $2-5 \%$ of children between 6 months and 5 years of age in Western Europe and the United States with the peak age between 12 and 18 months. Although febrile convulsions are seen in all ethnic groups, it is more frequently seen in the Asian population (5-10\% of Indian children and $6-9 \%$ of Japanese children). The incidence is as high as $14 \%$ in Guamese. ${ }^{(1)}$

Despite FC had a good prognosis, it is a difficult condition for parents to handle.

*Corresponding author: E-mail: drhanasalah@yahoo.com 
Concerns about the future health of the child are the most common cause of fear among the parents, including fear of recurrence, mental retardation, physical disabilities, and even death. FC in children can cause stress and anxiety for parents and may lead to disturbance in the parents' sleeping pattern, family's quality of life, and social activities. ${ }^{(3)}$

Inadequate knowledge regarding febrile convulsions can cause parental anxiety and incorrect attitudes, so correct and suitable knowledge of the relationship between fever and febrile convulsions and its usual good prognosis is important for lessening the parental anxiety and worry associated with febrile convulsions. Fever phobia may even be developed and each febrile episode of the child can be a nightmare for the parents. ${ }^{(4)}$

The lack of this knowledge can be overcome with health education which can improve parents' understanding and the ability of taking care of their children during the attack, so knowledge about febrile seizure is important for parents, especially knowledge regarding febrile convulsions when it will occur, seizure characteristics, how to do first aid management and how seizures can be prevented. Correct intervention can prevent complications such as head injury, mouth and teeth injury, and neck suffocation. ${ }^{(5)}$ Egyptian Family Medicine Journal (EFMJ)
This study was conducted to reduce morbidity and mortality of febrile convulsions in children by implementing and evaluating the effect of health education on improving the parents' knowledge and attitude regarding febrile convulsions in children. Up to my knowledge few studies were done in Egypt generally and in Sharkia governorate specifically.

Research question: Is health education affects the level of knowledge and attitude of mothers with febrile convulsive children?

\section{Methods}

\section{Study design and sampling method}

An intervention study was conducted (pre and post-test intervention) from January 2019 to July 2019. The sample was calculated to be 32 children after calculating it with an online open epi program with a percent of pre-test FC mother's knowledge was $11.2 \%$ and posttest percent was $64.4 \% .^{(6)}$

Zagazig district is the capital of Sharkia governorate and had the largest population in the governorate which administratively divided into 17 major districts according to Sharkia.gov.eg, 2018), the study was applied in randomly selected two family health centers which represent urban and rural residence in the district. The sample units Vol .4(1), May. 2020 www.efmj-eg.org 
were collected by simple random technique (participants attending the family health center asking for different health services). The practical part of the study is completed by attending the health center 4 hours/day, 2 days /week for 2 months.

\section{Study participants and data collection}

Children of both sexes aged from 6 months to 5 years and had febrile convulsions (single or recurrent attacks).

Exclusion criteria:

Children diagnosed with afebrile convulsions even if recurrent or convulsions secondary to organic disease e.g. cerebral palsy, meningitis, encephalitis, severe head trauma or intracranial tumors.

Parents were interviewed using Fahmy et al., $\mathbf{2 0 1 5}^{(7)}$ questionnaire to assess their sociodemographic characteristics including (mother and father education and occupation, sewage disposal, income .etc).

KACP questionnaire was developed by Huang et al. to assess the knowledge (Possible causes of febrile seizures, Necessary medical evaluation...), the attitude (parental opinions regarding febrile convulsions treatment, prognosis, examination ...), first aid home management during the attack (questions Egyptian Family Medicine Journal (EFMJ) related to recommended and none recommended management and first aid of febrile convulsions). ${ }^{(6)}$

The questionnaire took about 20 minutes to be filled in each time; patient education session took about 30 minutes and applied either individually or in small groups, 3 main prescheduled health education sessions were implemented in the health center targeting attended mothers not included in the study. Evaluation of the effect of health education done after 3 months of post health education.

\section{Administrative approval}

The study was approved by Sharkia health directorate. An official permission letter was obtained from the authority and directed to ElNahal family health center.

\section{Ethical approval}

Ethical considerations were taken through the whole study including fully informed participants with the purpose and nature of the study and then oral consent was taken from participants. Coded numbers for each participant were used to guarantee privacy. Official approval from the Institutional review board (IRB) was taken (ZU-IRB\#:4129).

\section{Statistical analysis}

Vol .4(1), May. 2020

www.efmj-eg.org 
The collected data were analyzed using Statistical Package for the Sociable Sciences version 24 (SPSS) software (Statistical Package for the Sociable Sciences, version 24, SPSS Inc. Chicago, IL, USA), Data were represented in tables, Continuous Quantitative variables e.g. age were expressed as the mean $\pm \mathrm{SD} \&$ median (range), and categorical qualitative variables were expressed as absolute frequencies (number) \& relative frequencies (percentage).

Social class was classified according to Fahmy and his colleagues ${ }^{(7)}$ into high (33.648), medium $(19.2-<33.6)$, and low $(<19.2)$ depending on the score calculated (48).

A suitable statistical test of significance (paired t-test) was used after checked for normality. The results were considered statistically significant when the significant probability was less than $0.05(\mathrm{P}<0.05)$. $\mathrm{P}$ value $<0.001$ was considered highly statistically significant (HS), and P-value $\geq$ 0.05 was considered statistically insignificant (NS).

\section{Results}

Regarding socio-demographic characteristics, the mean age of the studied febrile convulsive children was $3.03 \pm 1.5$ years old, about half of them were males (46.9\%), only $2.9 \%$ of the studied families had enough and saving income and most of them have moderate and high socioeconomic status (53.1\% and 40.6\%) respectively (Table 1).

The study revealed that only $18.8 \%$ of the studied sample had an adequate total knowledge regarding $\mathrm{FC}$, with $50 \%$ correct answer regarding the definition and if EEG or $\mathrm{CT}$ is necessary for every child with FC, while $65.6 \%$ of them answered correctly about that if anti-convulsant drugs are required for every child, $31.3 \%$ of them answered correctly if Every child with FC will have another FC attack in the future, $81.3 \%$ correctly answered if Children with FC can receive immunizations on schedule.

(Table 2).

There was a statistically significant change in knowledge about FC after application of health education program where the score of knowledge statistically elevated from (4.25 \pm $2.67)$ to $(9.18 \pm 1.33)$ after program application (table 3).

The total positive attitude of the studied mothers was $87.5 \%$ pre-health education, with $75 \%$ of the studied mothers strongly disagree that FC is due to possession by spirits or Folk medicine is necessary, while $53.1 \%$ of them strongly disagree that FC will become epilepsy, $75 \%$ of the studied mothers strongly 
agree that parents should take their children's temperature frequently and more attention and care are needed for a child with FC, 53.1\% strongly disagree that an FC attack is a lifethreatening event or FC can cause brain damage, only $15.6 \%$ of the studied mothers strongly agree that FC can be increased and complicated, only $18.8 \%$ strongly agree that lumbar puncture is acceptable, most of them $78.2 \%$ strongly disagree that shameful to have a child with FC.

(Table 4).

After implementing the health education the total positive attitude increased to $(46.12 \pm$ 1.33) after being $(35.62 \pm 4.26)$ with a high statistically significant difference (Table 5).

About one third of the studied mothers had an appropriate knowledge regarding first aid and home management during the FC attack, $96.9 \%$ of the studied mothers answered correctly about the importance of lowering the child's body temperature, while $78.1 \%$ of them answered correctly about observing seizures manifestations and duration and 50\% of them answered correctly concerning remain calm, shake the convulsing child, perform cardiac massage and restrain the convulsing child (Table 6).

There was a statistically significant change in Parental first aid and home management in response to FC after application of health education program where the score was statistically significantly elevated after program application (Table 7).

\section{Discussion}

Febrile convulsions are the most common type of convulsions in childhood. They are also one of the most common causes of hospital admissions in children under five years of age.(2) Despite having a good prognosis, many parents may even develop fever phobia because of lacking the appropriate basic knowledge to handle a febrile convulsion attack. ${ }^{(4)}$ The current study revealed that the mean age of the studied febrile convulsive children was $3.03 \pm 1.5$ years old, with no sex difference. This was similar to a study done in Libya ${ }^{(8)}$ which revealed that the majority of febrile seizure cases that were admitted to our department were found to be of equal sex incidence and a study conducted in Kayseri, Turkey ${ }^{(9)}$ found that the prevalence of $\mathrm{FC}$ was $4.2 \%$ in girls and $4.3 \%$ in boys.

Conversely, Sfaihi et al. (2012) $)^{(10)}$ in Sfax, Tunisia revealed that a slight predominance of FC in males yielding a sex ratio of 1.42 , and a study done In Kathmandu(11) revealed that males accounted for $62 \%$ and females $38 \%$. 
Regarding knowledge about febrile convulsion pre-program, the current study stated that $28.1 \%$ of mothers correctly answered about FC is rare after the age of 5 , but it was higher in a study conducted in Iraq (12) which found that $70 \%$ of parents believed that it will improve with age.

The current study stated that $50 \%$ of parents thought that computed tomography (CT) scan of the brain should be done for every child with FC; this is in consistence with Shibeeb et al. (2019) $)^{(\mathbf{1 2})}$ in Iraq who found that $60 \%$ of parents insist that the CT scan of the brain should be done for every child with FC. Conversely, in Iraq (13) whereas $76.4 \%$ of parents thought that there is no necessity for a CT scan.

There is a statistically significant change in knowledge about FC after application of health education program, This result was in an agreement with an Iranian study(14) that demonstrated that there was a significant increase in the mean score of knowledge of mothers $(\mathrm{p}<.001)$ in the intervention group compared with the pre-intervention time. Also in an agreement with Barzegar et al. $(2016)^{(\mathbf{1 5})}$ who stated that the handout assembles and the handout assembles plus verbal instructions about febrile convulsions for mothers demonstrated significant improvement in their knowledge post-intervention.

About the Attitude of mothers towards febrile convulsion pre-program, this study showed that $53.1 \%$ strongly disagreed that an $\mathrm{FC}$ attack is a life-threatening event or FC can cause brain damage, this is in agreement with a study done in $2016^{(15)}$ who reported in their study that the majority of mothers believed that FC episode is a serious condition which can cause brain damage and in $\operatorname{Iraq}^{(12)}, 69 \%$ of parents believed that FC attack is a lifethreating event, and regarding whether it can cause brain damage or not, $73 \%$ of them thought that brain damage will occur. These results can explain the parent's fear and anxiety during the attack of convulsion which makes it difficult for them to deal with.

Concerning the attitude of mothers toward lumbar puncture in the current study, only $18.8 \%$ strongly agree that lumbar puncture is acceptable, most of them $78.2 \%$ strongly disagree that shameful to have a child with FC, in contrast with Shibeeb et al. (2019) (12) in Iraq who found that $55 \%$ of parents believe that if it is necessary a lumbar puncture can be done.

Concerning attitude towards febrile convulsions after application of health education program, the study stated that there 
is a statistically significant change in attitude towards FC after application of health education program, this is in accordance with an Egyptian study ${ }^{(6)}$ showed that one quarter of mothers had a positive attitude about febrile convulsions before module implementation and this percentage was improved to more than half of them after module implementation with the mean score of attitude $18.42 \pm 5.84$ before and $24.71 \pm$ 6.76 after module implementation. This may be due to lack of knowledge and confidence of mothers when managing febrile convulsions while after gaining knowledge the mothers' attitude was improved. Also, the result was in an agreement with Taheri et al. (2014) $^{(\mathbf{1 6})}$ showed a significant increase in the knowledge, attitudes, and first aid home management of mothers after febrile seizures by educational intervention.

Conversely, a study done in Libya ${ }^{(8)}$ that studied auditing the attitude and knowledge of parents of children with febrile seizures and reported that, mothers practice and attitude did not change significantly after the introduction of the information leaflet and the majority of mothers did not know how to act toward a child with FC and take decision to take their child to the hospital.
Regarding parental first aid and home management in response to febrile convulsions pre-program, the current study $84.4 \%$ of studied parents immediately go to the doctor at the time of their children got febrile convulsions without first aid. This is in contrast with Najimi et al. (2013) ${ }^{(14)}$ in Iran who reported that less than one-quarter of the mothers took their children to the hospital or clinic without first aids at the time of FC. Also a study was done in Iraq ${ }^{(12)}$ found that only $25 \%$ of studied parents immediately go to the hospital or clinic at the time of their children got febrile convulsions without first aids, this is may be attributed to parental fear that their child may die, or they may have a poor understanding of the condition.

The current study showed that $43.8 \%$ Pry the convulsing child's clenched teeth apart and put something in his/her mouth. This close to Saudi study ${ }^{(17)}$ which stated that only $32 \%$ of mothers said that they tried to keep the child's mouth open with their fingers or any other objects to prevent tongue biting. Conversely, Shibeeb et al. (2019) ${ }^{(12)}$ in Iraq found that during attacks of fits, $64 \%$ of the parents tried to open a child's mouth and put something in, believing that it may avoid biting of the tongue. 
The study also found that $43.8 \%$ remove discharges from the child's mouth and nose during attacks of FC. At the same line, a study was done in Sri Lanka ${ }^{(18)}$ reported that $50.6 \%$ of mothers eliminated secretions and kept the child in a lateral position when the child is drooling.

As regards parental first aid and home management in response to febrile convulsions after application of health education program, the study stated that there is a statistically significant change in parental first aid and home management in response to FC after application of health education program. Similarly, a study in Nigeria(19) stated that insufficient emergency treatment and first aid measures were the standers among the parents before intervention while after the intervention, there was an improvement in the home practices of the mothers with regards to $\mathrm{FC}$ and these changes were statistically significant. Conversely, in Libya (8) the home management of mothers before and after the introduction of the information leaflet did not change significantly; their practice, however, was still inappropriate.

\section{Conclusion:}

The health education about FC could improve a mother's understanding and the ability of taking-care of their children in the case when children had febrile convulsions. Also, the efficiency of parental first aid home management could be evaluated and significant improvement could be achieved by giving adequate information to the parents. Creating awareness among parents through adequate health education and counseling could reduce their apprehension and fear.

\section{Recommendations:}

- Parents should receive health education about FC routinely with clinical care.

- Health care providers should provide counseling and health education for parents about febrile convulsions and how to deal with and provide simple educational pamphlets and posters about febrile convulsions.

- Similar studies should be conducted on a larger sample of children and longer duration in different areas of care like inpatient, emergency department and primary health units. 
Authors' contribution: H.S.S. contributed to the planning of the work, drafting of the work, data collection, patient education, reporting, literature review, revision of the manuscript, approval of the final version of the manuscript, and agreed to all aspects of the work. H.A.E. contributed to the planning of the work, drafting of the work, health education, data collection, statistical analysis, revision of the manuscript, approval of the final version of the manuscript, and agreed to all aspects of the work.

\section{Study limitations:}

- A short period of the study, so it was not available time to discover the effect of the education program.

- Larger sample was needed for the study to be extrapolated.

- Absence of a separate place for health education, so it was done in the same room of examination, so there were distractions and loss of concentration.

Conflict of interest: there were no known conflicts of interest associated with this publication.

Funding: there has been no financial support for this work that could have influenced its outcome.
Acknowledgment: we would like to express great thanking to the participants and family health centers' staff for their help to accomplish this work.

\section{References:}

1. Leung A.KC, Hon KL, Leung TNH. Febrile seizures: an overview. Drugs Context. 2018; (7):212536.

2. Srinivasa S, Anjum SK, Patel S, Harish S, Bhavya G. Parental knowledge, attitude, and practices regarding febrile convulsion. International Journal of Contemporary Pediatrics. 2018; 5(2):515-519

3. Sajadi M, Khosravi S. Mothers' Experiences about Febrile Convulsions in Their Children: A Qualitative Study.International Journal of Community Based Nursing Midwifery. 2017; 5(3): 284-291.

4. Parmar RC, Sahu DR, Bavdekar SB. Knowledge, attitude, and practices of parents of children with febrile convulsion. Journal of Postgraduate Medicine. 2018; 47(1):19-23

5. Rofiqoh S, Isyti'aroh. Effort to reduce anxiety levels among mothers using febrile convulsions educational package. Belitung Nursing Journal. 2018; 4(4):390-396.

6. Elbilgahy AA, Abd El Aziz RAE. Effect of implementing an educational module on 
improving mothers' knowledge, home management and attitude about febrile convulsion. Journal of Nursing Education and Practice. 2018; 8 (3): 1-11

7. Fahmy SI, Nofald LM, Shehatad SF, El Kadyb HM, Ibrahimc HK. Updating indicators for scaling the socioeconomic level of families for health research. J Egypt Public Health Assoc. 2015; 90:1-7.

8. Zeglam AM, Alhmadi S, Beshish A. Auditing the attitude and knowledge of parents of children with febrile seizures. African Journal of Neurological Sciences. 2010; 29(1): 3-8.

9. Canpolat M, Per H, Gumus H, Elmali F, Kumandas S. Investigating the prevalence of febrile convulsion in Kayseri, Turkey: An assessment of the risk factors for recurrence of febrile convulsion and for development of epilepsy. Seizure European Journal of Epilepsy Home. 2018; (55):36-47.

10. Sfaihi L, Maaloul I, Kmiha ., Aloulou H., Chabchoub I, Kamoun T, Hachicha M. Child's Nervous System. 2012; 28(10):1779-1784.

11. Ojha A, Shakya K, Aryal U. Recurrence Risk of Febrile Seizures in Children. Journal of Nepal Paediatric Society. 2012; 32(1):33-36.
12. Shibeeb NF. Altufaily YA. Parental knowledge and practice regarding febrile seizure in their children. Med J Babylon. 2019; 16 (1):58-64.

13. Ali AM. Iron deficiency anemia and febrile seizures case control study in children under 5 years. Iraqian Journal of Community Medicine. 2008; (4):285-90.

14. Najimi A, Dolatabadi NK, Esmaeili A. A., Sharifirad G. R. The effect of educational program on knowledge, attitude and practice of mothers regarding prevention of febrile seizure in children. Journal of Educational and Health Promotion. 2013; (2):26.

15. Barzegar M, Valizadeh S, Gojazadeh M, Jafarabadi MA, Zamanzadeh V, Shahbazi $\mathrm{S}$. The effects of two educational strategies on knowledge, attitude, concerns, and practices of mothers with febrile convulsive children. Thrita. 2016; 5:e33411.

16. Taheri Z, Rayyani M, Soltanahmadi J, Pouraboli B, Movahedi Z. The effects of febrile convulsion control program on knowledge, attitude, anxiety, and action of mothers. Medical Surgical Nurses Journal. 2014; 3(3):149-56.

17. Asiri NA, Bin Joubah MA, Khan SM, Jan MM. Maternal knowledge of acute 
seizures. Neurosciences (Riyadh). 2015; (20):346-9.

18. Abeysekara MS, Weerasekara MP, Wijesena BV, Perera RA, Sriyani KA, Kuruppu NR. Mothers' knowledge, believes and practices regarding febrile convulsions and home management. Proceeding of the 15th Open University Research Sessions (OURS 2017). 2017; p $219-23$.
19. Oche OM, Onankpa OB. Using women advocacy groups to enhance knowledge and home management of febrile convulsion amongst mothers in a rural community of Sokoto State, Nigeria. Pan African Medical Journal. 2013; 14(1). 
Table (1): Sociodemographic characteristics of studied febrile convulsive children $(n=32)$.

\begin{tabular}{|c|c|c|c|}
\hline \multirow{2}{*}{$\begin{array}{l}\text { Socioeconomic } \\
\text { characteristics }\end{array}$} & \multirow[t]{2}{*}{ Item } & \multicolumn{2}{|c|}{ the studied group } \\
\hline & & No. & $\%$ \\
\hline \multirow{2}{*}{ Age } & Mean \pm SD & \multicolumn{2}{|c|}{$3.03 \pm 1.5$} \\
\hline & Median (Range) & \multicolumn{2}{|c|}{3.5 (7 months-5 years) } \\
\hline \multirow[t]{2}{*}{ Sex } & Male & 15 & 46.9 \\
\hline & Female & 17 & 53.1 \\
\hline \multirow[t]{4}{*}{ Education of father } & $\begin{array}{l}\text { Illiterate/Read } \\
\text { write }\end{array}$ & 4 & 12.5 \\
\hline & Primary & 3 & 9.4 \\
\hline & Secondary & 13 & 40.6 \\
\hline & University & 12 & 37.5 \\
\hline \multirow[t]{4}{*}{ Education of mother } & Illiterate/ Primary & 6 & 18.7 \\
\hline & Preparatory & 1 & 3.1 \\
\hline & Secondary & 15 & 46.9 \\
\hline & University & 10 & 31.3 \\
\hline \multirow[t]{2}{*}{ Working status of the father } & No & 2 & 6.3 \\
\hline & Yes & 30 & 93.8 \\
\hline \multirow{2}{*}{$\begin{array}{l}\text { Working status of the } \\
\text { mother }\end{array}$} & No & 24 & 75.0 \\
\hline & Yes & 8 & 25.0 \\
\hline \multirow[t]{3}{*}{ Computer use } & Never & 12 & 37.5 \\
\hline & Sometimes & 16 & 50.0 \\
\hline & A lot of times & 4 & 12.5 \\
\hline \multirow[t]{3}{*}{ Per-capita income } & Not enough & 4 & 12.5 \\
\hline & Enough only & 27 & 84.4 \\
\hline & Enough and saving & 1 & 3.1 \\
\hline \multirow[t]{4}{*}{ Number of family members } & $\geq 7$ & 1 & 3.1 \\
\hline & 6 & 1 & 3.1 \\
\hline & 5 & 13 & 40.6 \\
\hline & $<5$ & 17 & 53.1 \\
\hline \multirow[t]{2}{*}{ Crowding index } & $\geq 2-<4$ & 17 & 53.1 \\
\hline & $<2$ & 15 & 46.9 \\
\hline \multirow{2}{*}{ Sewage /refuse disposal } & No & 1 & 3.1 \\
\hline & Yes & 31 & 96.9 \\
\hline \multirow[t]{3}{*}{ Social class } & Low $(<40 \%)$ & 2 & 6.3 \\
\hline & Moderate $(40-<70 \%)$ & 17 & 53.1 \\
\hline & High level $(\geq 70 \%)$ & 13 & 40.6 \\
\hline
\end{tabular}


Table (2): Mothers' knowledge about febrile convulsion preprogram $(n=32)$.

\begin{tabular}{|c|c|c|c|c|}
\hline \multirow[t]{2}{*}{ Knowledge about FC } & \multicolumn{2}{|c|}{ Correct answer } & \multicolumn{2}{|c|}{$\begin{array}{c}\text { Incorrect } \\
\text { answer }\end{array}$} \\
\hline & No. & $\%$ & No. & $\mathbf{0}$ \\
\hline $\mathrm{Fc}^{*}$ is epilepsy & 16 & 50.0 & 16 & 50.0 \\
\hline $\begin{array}{l}\text { Anticonvulsant drugs are required for every child with } \\
\text { FC }\end{array}$ & 21 & 65.6 & 11 & 34.4 \\
\hline Every child with FC will have another FC in the future & 10 & 31.3 & 22 & 68.7 \\
\hline FC is rare after age 5 & 6 & 18.8 & 26 & 81.2 \\
\hline Recurrent FC will cause brain damage & 12 & 37.5 & 20 & 62.5 \\
\hline Risk of subsequent epilepsy in FC is rare & 9 & 28.1 & 23 & 71.9 \\
\hline $\begin{array}{l}\text { It is necessary to put a protective device into the mouth } \\
\text { to prevent tongue injury during the convulsion }\end{array}$ & 17 & 53.1 & 15 & 46.9 \\
\hline $\begin{array}{l}\text { It is necessary to restrain the child during the } \\
\text { convulsion }\end{array}$ & 17 & 53.1 & 15 & 46.9 \\
\hline $\begin{array}{l}\text { It is necessary to do the mouth-to-mouth resuscitation } \\
\text { during the convulsion }\end{array}$ & 10 & 31.3 & 22 & 68.7 \\
\hline $\begin{array}{l}\text { Children with FC can receive immunizations on } \\
\text { schedule }\end{array}$ & 26 & 81.2 & 6 & 18.8 \\
\hline $\mathrm{EEG}^{* *}$ or $\mathrm{CT}^{\#}$ is necessary for every child with FC & 16 & 50.0 & 16 & 50.0 \\
\hline \multirow{4}{*}{ Total knowledge } & \multirow{2}{*}{\multicolumn{2}{|c|}{ adequate }} & $\mathbf{N}$ & 6 \\
\hline & & & $\%$ & 18.8 \\
\hline & \multirow{2}{*}{\multicolumn{2}{|c|}{ inadequate }} & $\mathbf{N}$ & 26 \\
\hline & & & $\%$ & 81.2 \\
\hline
\end{tabular}

*FC febrile convulsion **EEG electroencephalogram \#CT computed tomography 
Table (3): Mothers' knowledge about febrile convulsion before and after application of health education.

\begin{tabular}{|l|l|l|l|l|}
\hline \multirow{2}{*}{} & \multicolumn{2}{|l|}{ Knowledge about FC } & paired t & \multirow{2}{*}{ P-value } \\
\cline { 2 - 3 } & Pre -program & post -program & & \\
\hline Mean \pm SD & $4.25 \pm 2.67$ & $9.18 \pm 1.33$ & 18.09 & $0.000^{*}$ \\
Range & $1-8$ & $5-11$ & & $($ HS $)$ \\
\hline
\end{tabular}

$\mathrm{P}<0.05$ is statistically significant

HS: Highly significant

Table (4): Mothers' attitude towards febrile convulsion preprogram (n=32).

\begin{tabular}{|c|c|c|c|c|c|c|}
\hline \multirow[t]{2}{*}{ Attitude towards FC } & \multicolumn{2}{|c|}{ Negative } & \multicolumn{2}{|c|}{ Neutral } & \multicolumn{2}{|c|}{ Positive } \\
\hline & No. & $\%$ & No. & $\%$ & No. & $\%$ \\
\hline 1. FC is due to possession by spirits & 5 & 15.6 & 3 & 9.4 & 24 & 75.0 \\
\hline 2. FC will become epilepsy & 4 & 12.5 & 11 & 34.4 & 17 & 53.1 \\
\hline $\begin{array}{l}\text { 3. Parents should take their children's } \\
\text { temperature frequently }\end{array}$ & 5 & 15.6 & 3 & 9.4 & 24 & 75.0 \\
\hline 4. An FC attack is a life-threatening event & 8 & 25.0 & 7 & 21.9 & 17 & 53.1 \\
\hline 5. FC can cause brain damage & 8 & 25.0 & 7 & 21.9 & 17 & 53.1 \\
\hline 6. Folk medicine is also necessary & 3 & 9.4 & 5 & 15.6 & 24 & 75.0 \\
\hline 7. FC can be increased and complicated & 5 & 15.6 & 12 & 37.5 & 15 & 46.9 \\
\hline $\begin{array}{l}\text { 8. More attention and care are needed for a child } \\
\text { with FC }\end{array}$ & 24 & 75.0 & 2 & 6.3 & 6 & 18.8 \\
\hline 9. If necessary, lumbar puncture is acceptable & 11 & 34.4 & 15 & 46.9 & 6 & 18.8 \\
\hline 10. It is shameful to have a child with FC & 5 & 15.6 & 2 & 6.3 & 25 & 78.2 \\
\hline \multirow{4}{*}{ Total attitude } & \multirow{2}{*}{\multicolumn{2}{|c|}{ Negative }} & \multicolumn{2}{|c|}{ No. } & \multicolumn{2}{|c|}{4} \\
\hline & & & & & \multicolumn{2}{|c|}{12.5} \\
\hline & \multirow{2}{*}{\multicolumn{2}{|c|}{ Positive }} & \multicolumn{2}{|c|}{ No. } & & \\
\hline & & & \multicolumn{2}{|c|}{70} & \multicolumn{2}{|c|}{87.5} \\
\hline
\end{tabular}


Table (5): Mothers' attitude towards febrile convulsion before and after application of health education.

\begin{tabular}{|c|c|c|r|r|}
\hline & \multicolumn{2}{|c|}{ Attitude towards FC } & paired t & \multirow{2}{*}{ P-value } \\
\cline { 2 - 3 } & Pre-program & post -program & & \\
\hline Mean \pm SD & $35.62 \pm 4.26$ & $46.12 \pm 1.33$ & 15.69 & $0.000^{*}$ \\
\hline Range & $26-43$ & $43-48$ & & (HS) \\
\hline
\end{tabular}

$\mathrm{P}<0.05$ is statistically significant

HS: Highly significant

Table (6): Parental 1st aid and home management in Response to febrile convulsion preprogram $(\mathbf{n}=32)$.

\begin{tabular}{|c|c|c|c|c|}
\hline \multirow[t]{2}{*}{ 1st aid home management } & \multicolumn{2}{|c|}{ Correct answer } & \multicolumn{2}{|c|}{ incorrect answer } \\
\hline & No. & $\%$ & No. & $\%$ \\
\hline Lower the child's body temperature & 31 & 96.9 & 1 & 3.1 \\
\hline Protect the child on a soft and safe Surface & 13 & 40.6 & 19 & 59.4 \\
\hline Place the child on his/her side & 8 & 25.0 & 24 & 75.0 \\
\hline Remain calm & 16 & 50.0 & 16 & 50.0 \\
\hline Observe seizure manifestations and duration & 25 & 78.1 & 7 & 21.9 \\
\hline Rush the child to a doctor without first-aid & 5 & 15.6 & 27 & 84.4 \\
\hline Shake the convulsing child & 16 & 50.0 & 16 & 50.0 \\
\hline $\begin{array}{l}\text { Pry the convulsing child's clenched teeth } \\
\text { apart and put something in his/her mouth }\end{array}$ & 18 & 56.3 & 14 & 43.8 \\
\hline Attempt mouth-to-mouth resuscitation & 18 & 56.3 & 14 & 43.8 \\
\hline $\begin{array}{l}\text { Suck discharge from the child's nose and } \\
\text { mouth }\end{array}$ & 14 & 43.8 & 18 & 56.3 \\
\hline Perform cardiac massage & 16 & 50.0 & 16 & 50.0 \\
\hline Restrain the convulsing child & 16 & 50.0 & 16 & 50.0 \\
\hline Stimulate the convulsing child & 14 & 43.8 & 18 & 56.3 \\
\hline Too overwhelmed to respond & 11 & 34.4 & 21 & 65.6 \\
\hline \multirow{4}{*}{ Total parental $1^{\text {st }}$ home management } & \multirow{2}{*}{\multicolumn{2}{|c|}{ appropriate }} & No. & 9 \\
\hline & & & $\%$ & 28.1 \\
\hline & \multirow{2}{*}{\multicolumn{2}{|c|}{ inappropriate }} & \multirow{2}{*}{ No. } & 23 \\
\hline & & & & 71.9 \\
\hline
\end{tabular}


Table (7): Parental 1st aid and home management in Response to febrile convulsion before and after application of the health education program:

\begin{tabular}{|c|c|c|c|c|}
\hline & \multicolumn{2}{|c|}{ 1st aid home management } & paired t & \multirow{2}{*}{ P-value } \\
\cline { 2 - 3 } & Pre -program & post -program & & \\
\hline Mean \pm SD & $6.90 \pm 2.37$ & $12.28 \pm 0.88$ & 16.03 & $0.000^{*}$ \\
\hline Range & $2-12$ & $10-14$ & & (HS) \\
\hline
\end{tabular}

$\mathrm{P}<0.05$ is statistically significant

HS: Highly significant 
العربى الملخص

\section{أثر التثقيف الصحى على معارف وإتجاهات الأمهات فيما يخص التثنج الحرارى بقطاع الزقازيق, محافظة الثرقية}

هناء صلاح سعيد' هالة أحمد المغاورى

الخلفية: التشنج الحرارى في الأطفال هو عرض شائع في طب الأسرة وعيادات طب الأطفال. غالبًا ما يرتبط القلق الأبوي فيما يخص الحمى بعدم المعرفة الكافيه. الهاف: تقييم تأثنير برنامج التثقيف الصحي على معارف و إتجاهات الأمهات فيما يتعلق بالتشنج الحرارى. المنهجية وطرق البحث: أجريت دراسة تدخلية على 32 طفلا. نم تنفيذ الدراسة بقطاع الزقازيق الصحى والتى تمثل عاصمة محافظة الثرقية. تم اختيار مركزين صحيين لتمثيل القطاع. نم جمع معلومات المشاركين حول التشنج الحرارى عن طريق استبيان. النتائج: كثفت الدراسة أن 18.8 \% فقط من العينة المدروسة لديهم معرفة كاملة كافية بخصوص التشنج الحرارى ، وبالنسبة للاتجاه الإيجابي كانت النسبة 87.5 ٪ ، وحو الي ثلث الأمهات قيد الدراسة لديهن معرفة مناسبة فيما يتعلق بالإسعافات

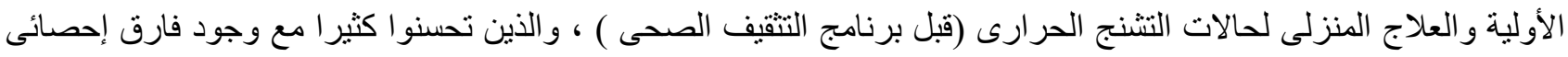
عالى بعد تنفيذ برنامج التنقيف الصحي. الخلاصة: يمكن تقليل الخوف لاى الوالدين من الحمى و التشنج الحرارى من خلال جلسات التثقيف الصحي المناسبة التي تناقش جميع جوانب المرض و المضاعفات المحتملة وكيفية الوقاية منها. 